\title{
New Perspectives on the Pitted Ware Culture in Northern Sweden
}

\author{
Niclas Björck
}

\begin{abstract}
During the last three years the number of coastal Pitted Ware sites in southern Norrland has increased immensely. The northern border of this cultural expression has been pushed to the northernmost part of Hälsingland, that is as far as our new surveys have reached. In 1993 the site of Fräkenrönningen was excavated. Due to the fact that the cultural layer on this site was excavated in it's totality - not just sampled - an analysis concerning the relation between artefacts and constructions on the site have been possible. These new sourcematerials has enabled us to pose questions about settlement structure and settlement patterns that would have been impossible to pursue without these large and consistent materials.
\end{abstract}

Niclas Björck, Länsmuseet Gävleborg, Box 746, SE-801 28 Gävle, Sweden.

Agriculture was introduced in Scandinavia in the later part of the fifth millenium $\mathrm{BC}$ as part of Funnel Beaker culture (Kihlstedt 1996:78f). In Sweden this culture has been documented from Scania to northern Uppland (Burenhult 1991:114). In the northern part of this area a regional group, the "Vrå culture", has been recognised (Florin 1958). The Pitted Ware culture is believed to have developed from the Funnel Beaker culture in connection with a climatic change around 3800 BC. The Pitted Ware culture is subneolithic, that is though chronologically part of the Neolithic and using ceramics, the subsistence is not based on agriculture but on hunting and gathering. The sites are usually coastal and in Sweden they are found in Scania up to southern Norrland. Gästrikland has for decades been viewed as the northernmost area of the Pitted Ware culture (Löfstrand 1969:84f; Blomqvist 1989; Burenhult 1991: 164). Many sites have been investigated, and the osteological material reveals that the subsistence was heavily dependent on seal and other marine resources. Chronologically the culture was connected with the Middle Neolithic during the period of approximately 3800-2900 BC (Burenhult 1991:158; Björck 1995b). In recent studies early datings have been noticed, indicating that this cultural expression was contemporaneous with the Vrå culture in northern middle Sweden (Åkerlund 1996; Kihlstedt 1996). In Gästrikland these early datings are indicated by sites approximately 48.5 MAPSL, and by one recently discovered ceramic site situated approximately 55 MAPSL (Björck in prep). Sites in this area situated 45 MAPSL have been chronologically pinpointed to approximately 3500 $\mathrm{BC}$. The 55 meter horizon in Gästrikland ought to be at least 800 years older than this.

During the transgressive phases of the Litorina Sea, the large amount of water that at this time passed through the straits between Scania and Denmark from the Atlantic increased the salinity of the water we call the 
Baltic Sea (Gräslund 1978:227; Hallgren 1993; Björck 1995b). The high salinity of the Litorina Sea during the Middle Neolithic had an impact on the fauna and thus changed the economic basis for coastal dwelling. An important part of this change is the seals, especially Phoca Groenlandica, which have proved to be common in the Pitted Ware materials of southern Norrland as well as in other parts of Sweden, Åland and Finland (Siiriäinen 1969; Ericson 1989; Olson 1994). Such changes might have been of importance for the transformation of material culture during this phase of prehistoric Sweden.

The relations and affinities between the Neolithic cultures have been discussed for a long time (Malmer 1962; Browall 1991; Kihlstedt 1996:74; Olsson 1996:40ff). The recent discoveries in northern Sweden presented below have cast some doubt on the long-held assumptions concerning the relation between the Neolithic cultures (Björck $1995 \mathrm{~b}$; in press a). Scholars have generally agreed that the Pitted Ware culture has had it's northernmost sites in the southernmost part of the research area (marked in fig. 1). The spatial distribution of the culture thus corresponded to the distribution of the Funnel Beaker culture and Battle Axe culture. In fact this interrelation in connection with an appearent chronological succession and some typological similarities has strengthened the idea that the Pitted Ware culture developed from the Funnel Beaker culture. The idea of a northern limit for the Pitted Ware culture not far from the northern limit of the Funnel Beaker culture and Battle Axe culture has been proved wrong by the surveys. It now appears that the distribution of these archaeological cultures is not identical (cf. Browall 1991). Some doubts have also been thrown on the above-mentioned views by the recent datings. According to these datings, the Pitted Ware culture has appearently coexisted with the Funnel Beaker culture during the Early Neolithic and with the Battle Axe culture during the latter part of the Middle Neolithic sequence. This indicate that a more complex relationship than a development initiated by climatic changes existed between the Funnel Beaker culture and the Pitted Ware culture. I believe that the material presented in this article will aid us in discussions concerning the Middle Neolithic cultural affinities, and not only in the reconstruction of the prehistoric situation in the Gävleborg region.

\section{THE RESEARCH AREA}

In 1927 two sites of Pitted Ware culture were found in Mårtsbo ca. 15 kilometers south of Gävle, which at that time were the most northern known (Jonsson 1958:26ff). During the 1930's some additional sites were found near the city of Gävle, in Valbo parish, Gästrikland. When the author commenced working in Gävleborg there were in all seven coastal Pitted Ware culture sites known in the area. There were also some sites that were not coastal, for example Ista in Österfärnebo parish and Orsand in Leksand parish. Further there were some ceramic sites known from Hälsingland. These sites were notable because they were separated from the main part of the Middle Neolithic ceramic sites by 200 kilometers. Some of the material from the partly excavated site of Hedningahällan seemed different from the more southern settlements. Because of the difficulties in relating these finds to the southern Pitted Ware culture, these sites were grouped as "Hälsinge ceramics" (Arbman 1945; Baudou 1992:93; Schierbeck 1994). As a result, the Pitted Ware culture has been thought to have its northern border at Gävle around $61^{\circ}$ north (Löfstrand 1969; Björck 1995b; in press a).

In 1993 the author found the sites of Fräkenrönningen and Southern Mårtsbo during survey work for the new motorway (E4); these sites were excavated later in the same year. Other sites of the same type have also been discovered in this region (Andersson 1994). In 1995 the author discovered the site of Vedmora in Enånger parish, Hälsingland (Björck 1996b). Material from this site is very 
similar to material found in the area around Gävle and supports the idea of a close connection between the ceramic sites in the northern part of Gävleborg. A rescue excavation done by the county museum of Gävleborg in 1995 also supports this view (Holm 1995).

Before presenting the materials, I will explain the circumstances that make southern Norrland an especially suitable area for an analysis of settlement patterns and intra-site structures. The northernmost area of the Middle Neolithic cultures offers an unique opportunity to study these problems. Postglacial isostatic movements are of great importance for archaeological studies in northern Sweden (Baudou 1977:33ff, 1992:18; Broadbent 1978:19, 1979, 1982). This phenomenon has caused the coastal sites of the Middle Neolithic in Gästrikland to be situated at levels between 40 and 50 MAPSL. Today the shoreline displacement in this area exceeds 0.6 meters in one hundred years. During the Middle Neolithic the displacement can be approximated to have been more than 1 meter in the same amount of time. A sea-level declining at this rate had a great impact on the landscape in which the Pitted Ware culture existed, that is, in a fairly short period of time the settlements became unsuitable for coastal dwelling. This is especially apparent in a relatively flat and low profilated landscape as that in southern Norrland. These circumstances have usually caused coastal settlements in the north to be more synchroneos and therefore have a more homogeneous material than sites in southern Sweden. These northern sites can also be expected to have quantitatively less material, and hence they might be more difficult to detect (cf. Miettinen 1990:56). Another consequence of the shoreline displacement is that structures on these synchronic settlements can be expected to be less damaged or diffused by later prehistoric activities. Due to the fact that settlement sites have been unsuitable for coastal dwelling after a relatively short period of time, many sites have been left undisturbed in the forests up to present time. In the southern parts of Sweden the shoreline displacement is less rapid and the locations have been suitable for coastal dwelling for longer periods of time. I also believe that this area may help us to better understand questions concerning Middle Neolithic cultural affinities.

\section{SURVEYING}

When I started to study the Pitted Ware culture in southern Norrland, I realized that the empiric situation had to be improved in order to enable an analysis of settlement patterns and intra-site structures. Hence my first problem was to find the areas in need of improvement, and create a strategy to collect missing data. In studying settlement patterns it is important to have a fairly good picture of the actual distribution of sites during the period studied. I have tackled this problem by initiating a survey of the area of investigation (fig. 1). The problems with this approach are obvious; it is of course impossible to make a complete survey of an area such as the one under study, which comprises: northern Uppland, Gästrikland and Hälsingland (c. 40000 $\mathrm{km}^{2}$; approximately the size of the Netherlands). This problem has been partly solved by the fact that the settlements used to be coastal, during the period approximately 3900 to 2600 BC. On the basis of the land upheaval in the area of investigation we know that the prehistoric coastline of this chronological horizon was located between 55 and 35 MAPSL, depending on whether you are in the northern or in the southern part of the research area. The shoreline displacement during this chronological horizon in the area of research has been approximately 10 meters in height. It was slightly more in the north and slightly less in the south. This has enabled us to limit the area of survey, but even with this limitation the actual area of research is immense.

An initial problem of the survey work was raising funds. In due time solutions were found, with contributions made by the com- 
panies of Korsnäs, Stora and Mellanskog. The work was also supported with maps by Peter Norman at the Central Board of National Antiquities. The project was also highly dependent on previously unemployed personnel and educational funds granted by the unemployment bureau. This, of course, had its difficulties as the personnel working on the project had no previous archaeological experience. At the same time this meant that their work would be without the kind of predjudice that archaeologists often have. We tend to think in terms of "good spots" while surveying, for example, an inlet, archipelago or the mouth of a river. When we have selected suitable areas we look for sandy slopes facing south. These ideas are relevant of course, but what other categories were important for the establishment of sites during the Stone Age? If surveys are conducted with the above ideas in mind, the result will surely be many new sites, but perhaps not the kind of sites which can enlighten us on new categories of importance for site location. We may simply not find the full range of possible site locations. The inexperienced surveyer

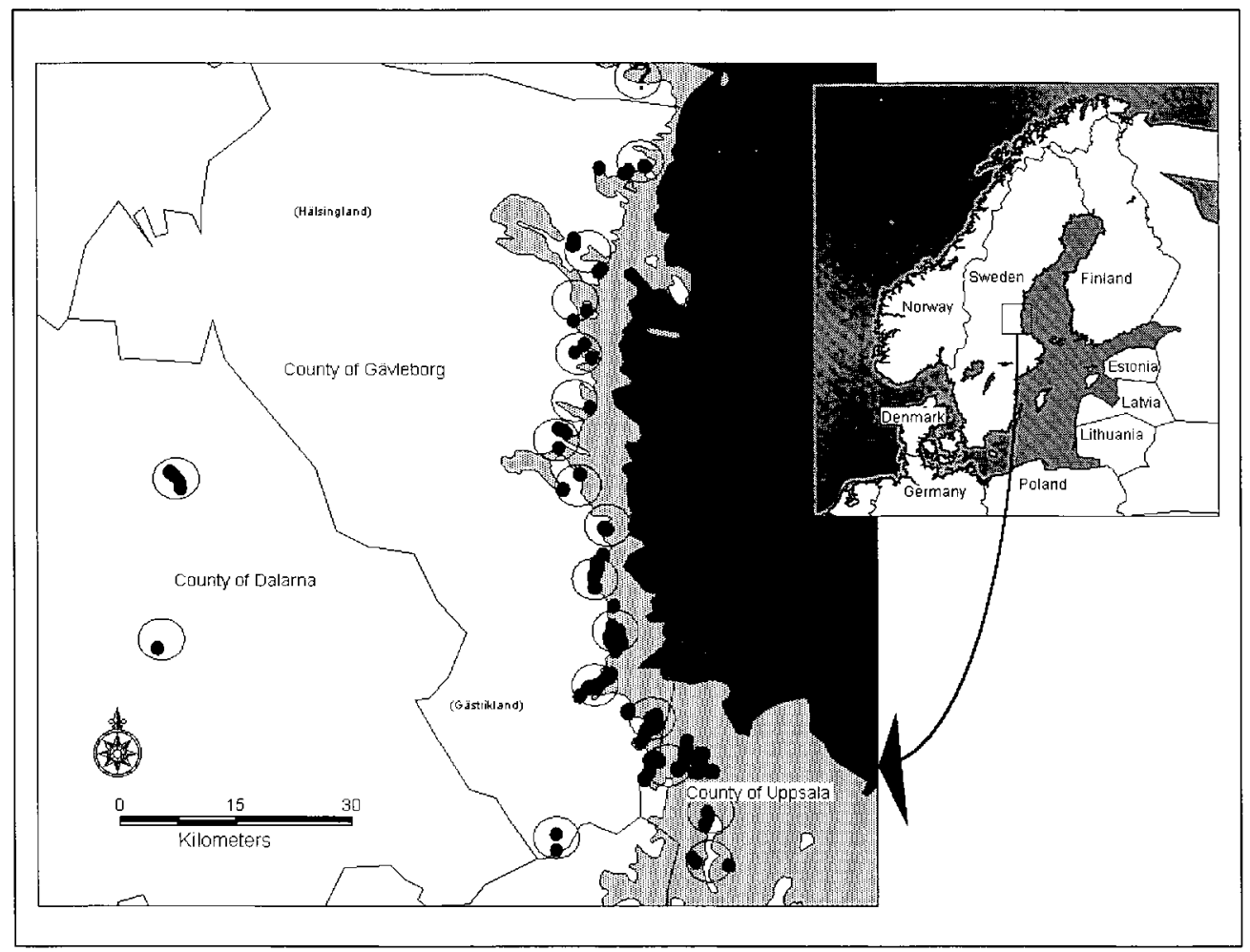

Fig. 1. Scandinavia and bordering countries with the area of research marked. The subneolithic culture is found in most of the countries shown on the map. The subneolithic complex is suitable for regional division but I believe it ought to be viewed as an affined cultural expression. A Neolithic, coastal tradition with a ceramic technology heavily dependent on marine resources. Left: The research area of Northern Uppland, Dalarna, Gästrikland and Hälsingland, with the distribution of Middle Neolithic settlements. The groups usually consist of 10 to 30 settlements. 
might give more attention to locations which we would have considered very improbable, and thus give us material which will force us to rethink our initial ideas. Viewed this way, it is clear that the organization that was forced on the project actually might have been beneficial to the results (Björck 1996a; in prep.).

In order to create a material that aimed at revealing the settlement patterns of the Middle Neolithic of southern Norrland, a strategy had to be worked out. In order to make the gathering of data as objective as is possible, the work-team was evenly distributed over Gästrikland, from Dalälven to Axmar. Every team was given an area the size of the zone between 40 and 50 meters above present sealevel on an economic map $\left(25 \mathrm{~km}^{2}\right)$. The size of the area varied, depending on, for example, the dept of the archipelago that once existed in the respective area. An effort was also made to distribute the workers so that the quality of the survey would be the same over the whole of the prehistoric coastline. This was done in order to retrieve a material that was as representative as possible. The expected result of this work would be an even distribution of sites along the whole coastline, because the same effort and the same method have been used over the whole area of research. As the work continued a picture quite different from the expected emerged, however. The settlements seemed to be situated in groups, with areas without settlements between them. In fig. 1 the results of the surveys and previous knowledge are presented; every dot represents a subneolithic settlement. The explanation of this settlement pattern may be of cultural or natural origin. Further studies are currently being conducted by the author in order to better understand this pattern. There is an obvious and clear relation between the settlement groups and river mouths during the Middle Neolithic. At the same time there are river-mouths without settlements and settlements not situated by river mouths. As a consequence the natural environment hypo- thesis can not explain the patterning alone. I believe that this settlement pattern may be social in origin. Explanations of settlement patterns in other areas have been oriented towards nature/economy, social organization, or historic origins (Österholm 1989; Forsberg 1985).

\section{DGPS-REALTIME DIFFERENTIAL NAVIGATOR AND GIS-APPLICATIONS} In order to use the possibilities inherent in the above-presented material, the demands for accurate measurements and demarcations are evident. The Middle Neolithic period has been estimated to be about 1000 years, during which time the sea-level regressed approximately 10 meters in Gästrikland. In the Mårtsbo/Hanåsen group the shoreline displacement was between one and three kilometers. This knowledge has enabled us to use the shoreline displacement as a powerful tool in chronological analysis. As can be seen in the diagram (fig. 2), the sites seem to cluster at certain levels above present sea-level. This was possibly caused by the variation between isostatic and hydrostatic movements. I believe that there is a possible connection between the more frequently settled levels and the litorina transgressions in the southern parts of Sweden (Olsson 1996; Åkerlund 1996). In this perspective hydrostatic elevation would retain the same sea-level for a period and then be followed by a faster shoreline displacement. In some areas directly above the settlements there has often been a prevalance of cobble stone beach ridges. These have probably been created when water washed out lighter material from the eskar materials during the periods of temporarily stationary shoreline.

Through the use of DGPS and GIS it has been possible to obtain and handle a large enough sample of data to make questions concerning settlement patterns fruitful. The GIS-system has also been important in the handling of excavated materials and in the subsequent intra-site analysis. In this work we 
have been able to ask questions about quantitatively large materials and alter them if neccessary. Here it should be noted that we work with the totality of the cultural layer from the site and not, as is common, a sampled part of it. In the section concerning contextual sites, an example of this type of analysis is presented.

Due to the above-mentioned marked isostatic movements in Norrland, it has been possible to get a reasonable understanding of the chronology of the sites through their position above present sea-level. In order to obtain material suitable for the analysis of chronology and settlement patterns the DGPSsystem has been used. This very accurate measurement system has enabled us to determine the settlements' size, their spatial extension, and their present level above sea ( \pm 1 meter). Usually the measurement was even more accurate than stated, faults down to $0.2-0.5$ meters were common. The DGPS has also been used in order to make the mate- rial more substantial than just a point on a map. With the above-described method, it has been possible not only to approximate the sea-level at time of settlement but also to measure the size of the cultural deposits on every site. The method used to determine these for the study of settlement patterning crucial values has been systematic sampling. Below I will critically evaluate this method of excavation and the questions it might shed light on. Systematic sampling is very suitable for demarcation, although it is unsuitable for the intra-site level of investigation. The method can be described as the laying out of test pits every fifth meter in a coordinate system over an area. The pits have only been dug in order to see if there was Middle Neolithic material present. If material was found in a pit, another pit further away from the epicentrum - i.e. the first pit - was dug. This continued until the pits no longer contained material, that is when the outskirts of the sites were reached. In this area the pits were dug

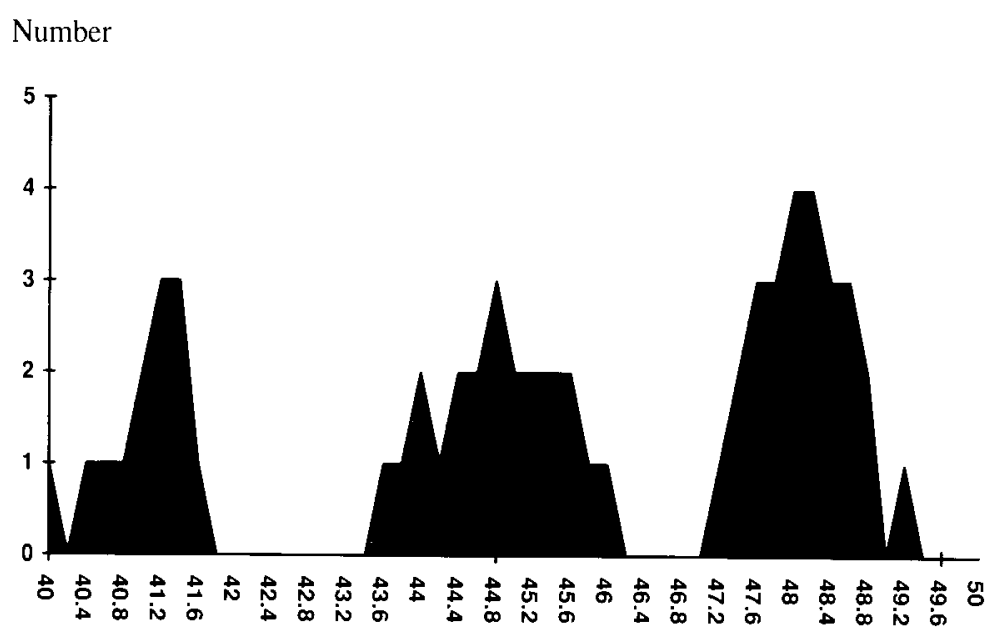

MAPSL

Younger (Pitted ware culture) Middle (Pitted ware culture) Older (Pitted ware culture)

Fig. 2. Number of settlements and their respective position above present sea-level as documented during the 1995 fieldwork. Notice the tendency for the settlements to cluster at three levels on the height scale. This has been interpreted as a result of continuous land upheavel and a fluctuating sea-level. A comparative study of shoreline displacement curves from other areas and transgressions may be of value (cf. Akerlund 1996; Olsson 1996). 
more closely together in order to obtain more exact values of height above present sealevel and settlement size.

The strong isostatic movements in the area of investigation have also resulted in a horizontal stratigraphy between sites, that is, the younger sites at around 40 meters above present sea-level further to the east, and the older sites around 48 meters above present sealevel in the west. In my analysis I have worked with three chronological periods as suggested by the diagram (fig. 2). The measurements are, however, of such good quality that they can be used for making an even more precise grouping of the settlements.

The high precision of the DGPS-instruments have thus enabled me to use the height above present sea-level as a chronological variable. The size of the cultural deposits, that is the settlement size, can be used as a social/ functional variable in analysis. The chronology obtained from the measurements and the level above the present sea has been tested against the typology of material retrieved from the sites.

\section{SETTLEMENT PATTERNS}

In 1993 there was only a handful of coastal settlements known in the research area and they were all found in two of the settlement groups. During the surveys new settlement agglomerations have been located at even distances from Torslunda in the south to Hamrånge in the north. The pattern that emerged was tested last autumn at even distances towards the north. Some areas were selected as possible settlement agglomerations. The limited surveys done in these areas all revealed settlements. It seems plausible to suggest that the pattern documented in Gästrikland continues towards the north. The work has continued during the summer of 1996 , and the results that are registered at the time of writing will be included in the figures. During the winter of $1995 / 96$ the stray finds in the research area were compiled, and the result was made into a database which is spatially presented (fig. 3). The rings are placed so that they encircle the settlements (fig. 1), that is the settlement groups. It is quite clear from this figure that along the Middle Neolithic coastline stray finds are found at the settlement groups documented by the survey and not between them. Almost every group of settlements found by the survey have a few strayfinds tied to it, rarely are the stray finds found at the Middle Neolithic coastline between the settlement groups. The distribution of stray finds was not compiled prior to the survey and can therefore be viewed as an independent source material that strengthens the argument for the observed pattern. There are also a couple of groups with few or no artefacts, which are situated within low populated areas of today. It is evident that the stray finds may be used to study settlement patterns, but some problems concerning representativeness are made clear by the surveys. If used with caution, the stray finds might be an important sourcematerial. The same types of stray finds as found along the Middle Neolithic coastline in the research area are also found further to the north (Baudou 1977:39ff). Therefore subneolithic sites not yet found may be expected in the northern counties.

The artefacts found by serendipity over the years, strayfinds ( $\mathrm{Sw}$. lösfynd), are one category that could be suitable for this kind of analysis. This material does, however, have its problems. Firstly, it is predominantly found in cultivated land and may show the intensity of agriculture during the last one hundred years, as well as prehistoric activity. Secondly, the material might also be altered by one or a couple of enthusiasts working in an area hence multiplying the reports from that region. Connected with this source-critical problem is also the overrepresentation of areas which are densely populated in modern times. As is clear, stray finds as a material are quite possible to use, but are far from ideal when analyzing settlement patterns.

The Baltic Sea regressed 10 meters in 
height during the approximately 1000 year period of Middle Neolithic coastal dwelling. Since the landscape in the southern part of Gästrikland is rather flat and level this land- upheaval have caused the sea to regress between 1 to 5 kilometres in length during the Middle Neolithic period. I will use the Mårtsbo/Hanåsen archipelago to illustrate the

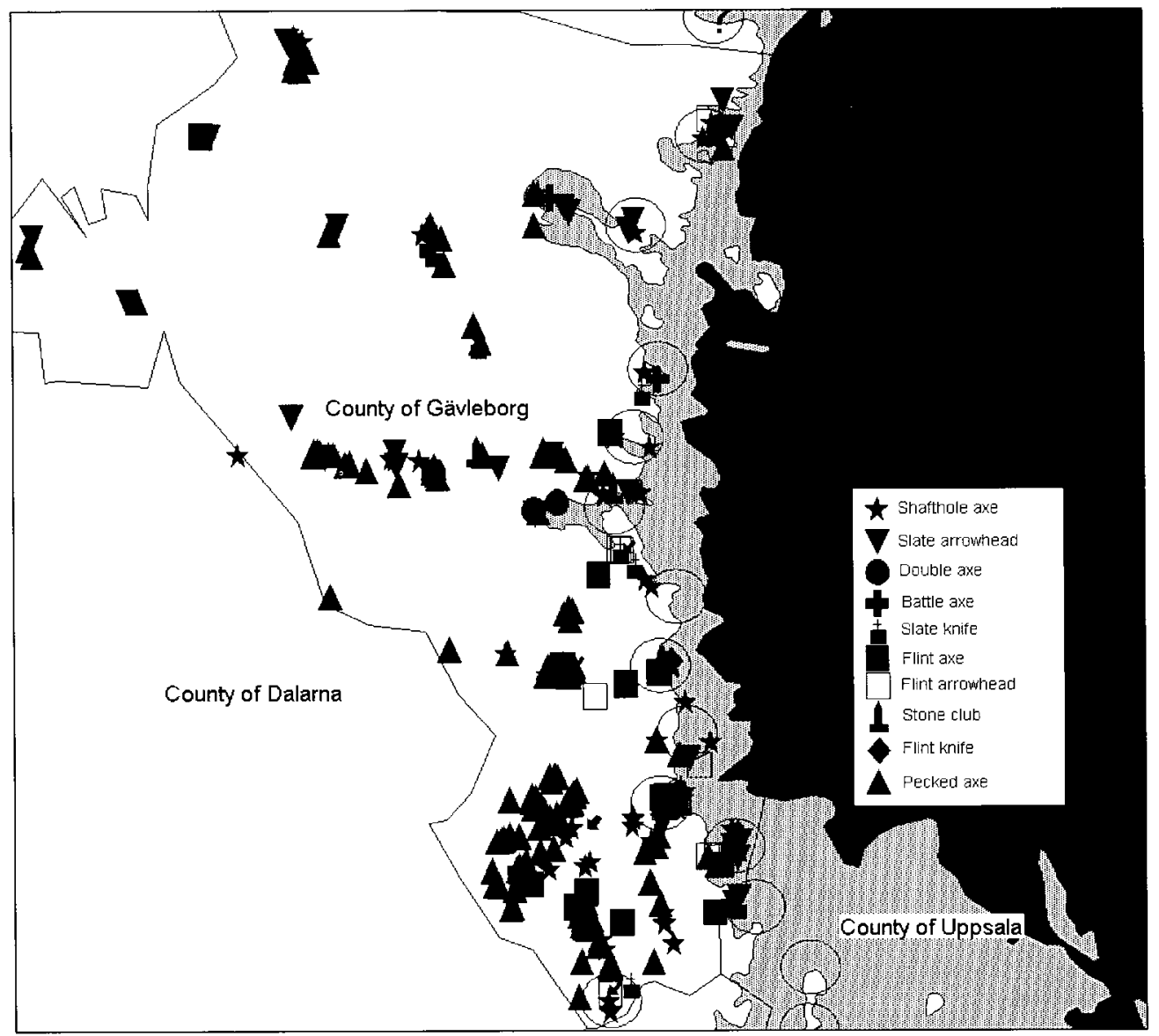

Fig 3. Dispersion of artefacts from the Stone Age that have been found during the 19th and 20th centuries in the county of Gävleborg. The coastline for the time of the early Pitted Ware culture is depicted, the circles represent settlement agglomerations (fig. 1). Note that there is a group of finds tied to almost every circle, i.e., group of settlements. Between these groups are areas with no registered finds. One exception is Tönnebro, an area which has very few registered finds. This area has been the border between Hälsingland and Gästrikland for at least a thousand years. "Ödmården" can be interpreted as the desolate forest. Perhaps this is an explanation as to why no artefacts have been found in the area: it is still relatively uninhabited today: There is an obvious distinction between the finds that have been found in the western part of the county (Mesolithic) and the finds from the eastern parts (Neolithic), although there are sporadic Neolithic artefacts in the west. 
power of shoreline displacement as a chronological tool even in a relatively short time period as the Middle Neolithic.

In the Marrtsbo/Hanåsen archipelago the shoreline was displaced at an average of two hundred meters in one hundred years. It is thus plausible that the sites have not been used for a period longer than one or at the most two hundred years. During the last phase of settlement in the Mårtsbo/Hanåsen group there are six settlements at approximately 40 MAPSL. This isostatic level has been chronologically pinpointed to approximately 3000 $\mathrm{BC}$ through the excavation of the settlement Fräkenrönningen. Fräkenrönningen was situated by a seashore 40.5 meters above present sea level and hence is connected with the younger isostatic levels of the Pitted Ware culture as displayed in fig. 2. Fig. 4 shows the Mårtsbo/Hanåsen archipelago as it appeared during the three chronological horizons (isostatic levels) of the Pitted Ware culture, as suggested in the diagram above (fig. 2).

The marked regression of the shoreline has also caused the sites to be used during rather short periods of time, a situation that has proven important with regard to the possibilities for intra-site analysis. The sites have usually not been disturbed by activity since the time they were abandoned by the coastal hunters of the Middle Neolitic. This can be illustrated by the settlement of "Stordalen", which has been measured to be about 40.9 meters above present sea-level (the western-

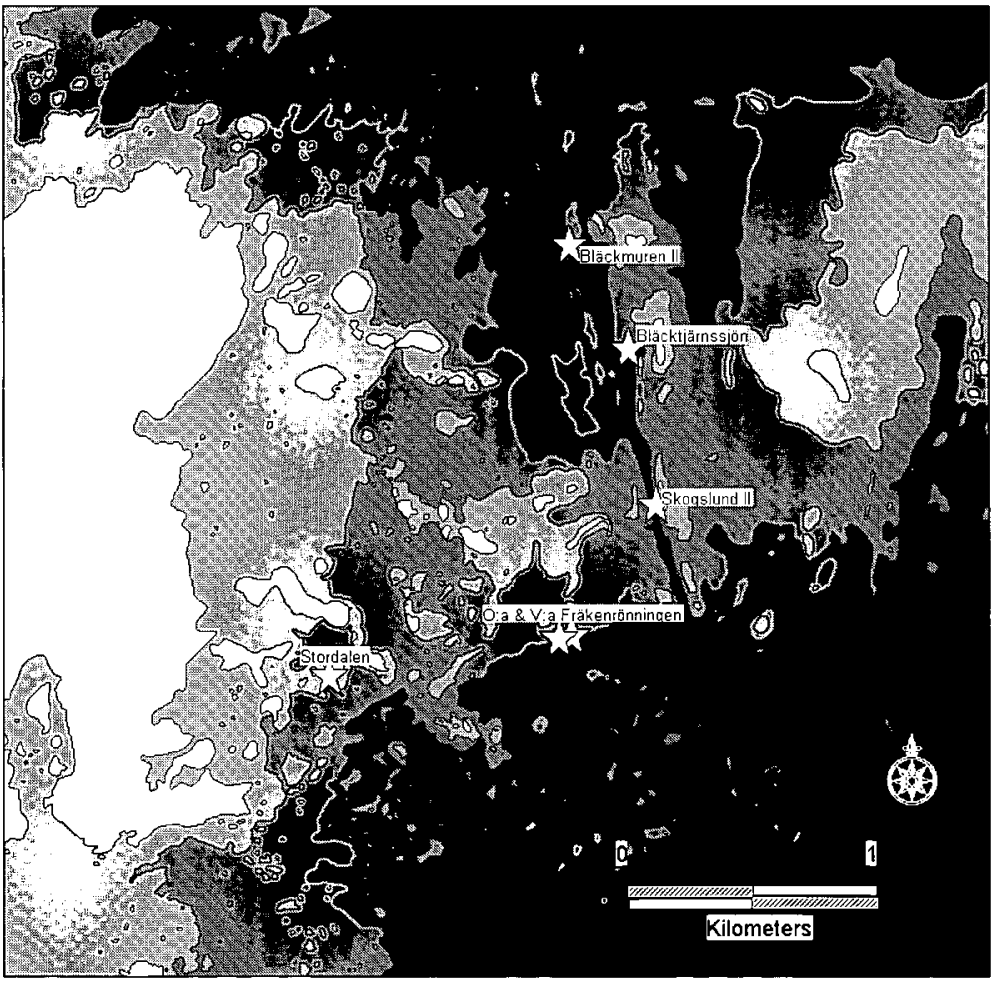

Fig. 4. Mårtsbol Hanåsen archipelago approximately 4000,3500 and $3000 \mathrm{BC}$, i.e., 50 , 45 and 40 MAPSL. Settlements by DGPS measuring tied to the youngest chronological period are displayed as stars on the map. 
most site in fig. 4). This site was situated on a small plateau below a steeply descending ridge. The isoritm 40 meter above present sea-level is situated approximately half a kilometer away from this site. The landscape around the settlement is obviously extremly flat. Just at the end of the cultural layer on this site is a small slope ca 0.5 meter and then the landscape is flat. This site have obviously been in use when the sea was at a level 40.5 to 40.9 meters above present sea-level. Before as well as after this period the site of Stordalen could not be used for coastal dwelling. A fall of only 0.9 meters of the sea-level at this site caused the shoreline to regress nearly half a kilometer. This of course would make attempts at coastal settlement quite impossible at this location after a relatively short period of time. Hence the period of this site can be pinpointed to the same chronological interval as Fräkenrönningen.

\section{CONTEXTUAL SITES}

The material from actual excavations has also changed during the last couple of years. The excavation of the settlement Fräkenrönningen was an indication that coastal sites in this area are relatively well preserved and synchronous, that is they have not been used during long periods of time. The material retrieved during the excavation of 1993 has enabled us to make an intra-site analysis. This angle has revealed an organization reflected not only in constructions, but also in the relation between features, constructions and the contents of the cultural layer. If archaeology aims at retrieving material that can enlighten us on the use of space as a reflection of social, ideo-

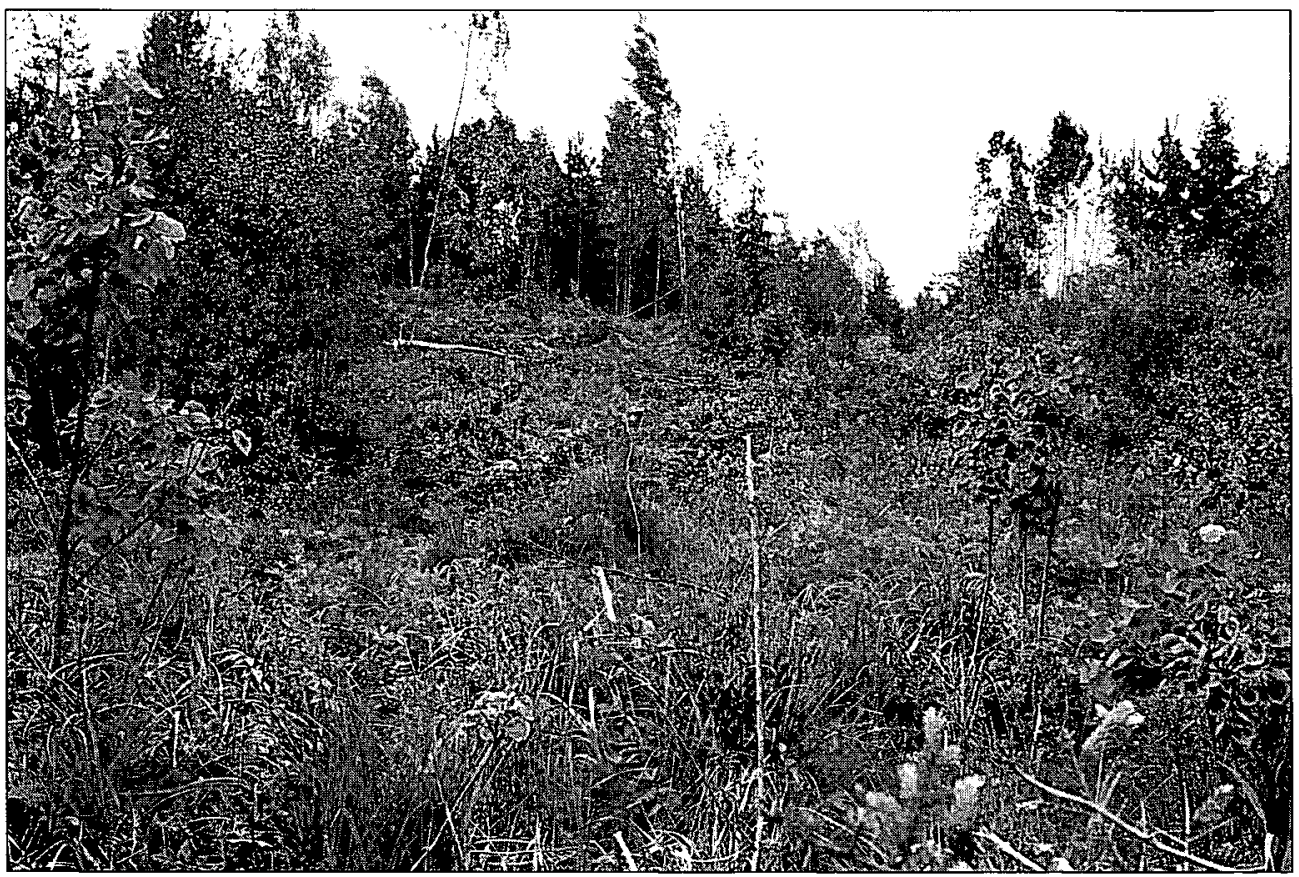

Fig. 5. The Fräkenrönningen site prior to the archaeological excavation. The central settlement area is at the crest of the slope. The picture is taken from the prehistoric shoreline towards the north.

Photo: Niclas Björck. 
logical or religious aspects of prehistoric life, we will have to conduct excavations that document all of the above-mentioned variables and perhaps even others. In this connection I can also mention that the Vedmora site in Enånger parish, Hälsingland, was investigated in a similar way during the summer of 1996. In both cases phosphate samples were taken over the whole site. The relative values may give us a deeper understanding of depositional patterns, for example.

The site of Fräkenrönningen was situated on a horizontal plateau in a densely forested slope facing south. The geological material on the site was mainly morain with some boulders of considerable size surrounding the settlement plateau. An area of approximately $350 \mathrm{~m}^{2}$ had been cleared in the otherwise quite stone-rich slope (Björck 1995a; in press b). At the southern end of the slope a marsh, Fräkenrönningsmyran, delimits the settlement. According to the height above present sea-level, this site was used during the latest phase of the Pitted Ware culture. When this sea-level is drawn on the site-plans, it becomes apparent that there was a lagoon south of the slope at the time of settlement. In this part of the swamp, water-drenched organic material was retrieved. The distribution of artefacts on the site reveals a path which leads from the plateau towards the lagoon. The spatial distribution of osteological material, ceramics and quartz shows a similar pattern (Lundblad 1994; Olson 1996). Five C14 samples have been analyzed from the site, and the datings pinpoint the time of use to the period $3037-2818 \mathrm{BC}$. This means that the site was probably not in use for a period Ionger than approximately 200 years. This period may very well have been shorter, however, as all samples overlap and could theoretically be from a very short time period. Stratigraphic evidence does imply, however, that there was a settlement for some time. The plateau was a fairly horizontal area situated approximately 43 MAPSL in the otherwise steep slope. Peripheral to this cleared area, the frequency of stones was higher than normal (fig. 6). This was obviously because the stones which had been cleared from the central part of the settlement had been deposited there. This hypothesis is strengthened by the fact that artefacts were found directly beneath the stones in the area of hutfoundation III, that is the stones had been put there after or during the time of the settlement, and not enough time had elapsed for the artefacts to be covered with debris. Since there was no evidence of activity on the site after the time of the Pitted Ware settlement the likelihood of these stones being cleared during a later period is insignificant. Therefore this clearing has been done as part of the Stone Age settlement activities.

\section{CONSTRUCTIONS AND INTERNAL RELATIONS}

The correlation between the distribution of finds and the cleared plateau is very strong, although some other patterns of deposition are visible. For example, in the central part of the terrace there is an area which has very few finds. This low frequency of finds is the only thing which distinguishes this part from the rest of the terrace. Possibly this area has for some reason intentionally been kept fairly clean compared with the surrounding areas. These dispersions are possible to relate to the organization of the settlement. The hutfoundations encircle two such areas with a lesser frequency of finds. In the central part of these two "cleaned" areas are the hearths situated. There are mounds found around the settlement in the outskirts of the cleared plateau. The mounds consist of sand and splintered, fire-cracked rocks. Only one (A21) of twenty-five such mounds is situated on the cleared area; this mound is also the western limit for the older type of ceramics. This type is mainly found in the eastern part of Fräkenrönningen. Both the dispersion of ceramics and the stratigraphical evidence support the suggestion that A21 marks the outskirts of the settlement during the early phase, and 
hence this mound was also placed in the same type of location as the others during the older phase. The mounds are situated near the hutfoundations in the periphery of the settle- ment. Close to most of the mounds are cooking-pits. The sand in these mounds probably was dug out of the pits while they were constructed. After this the mounds grew in

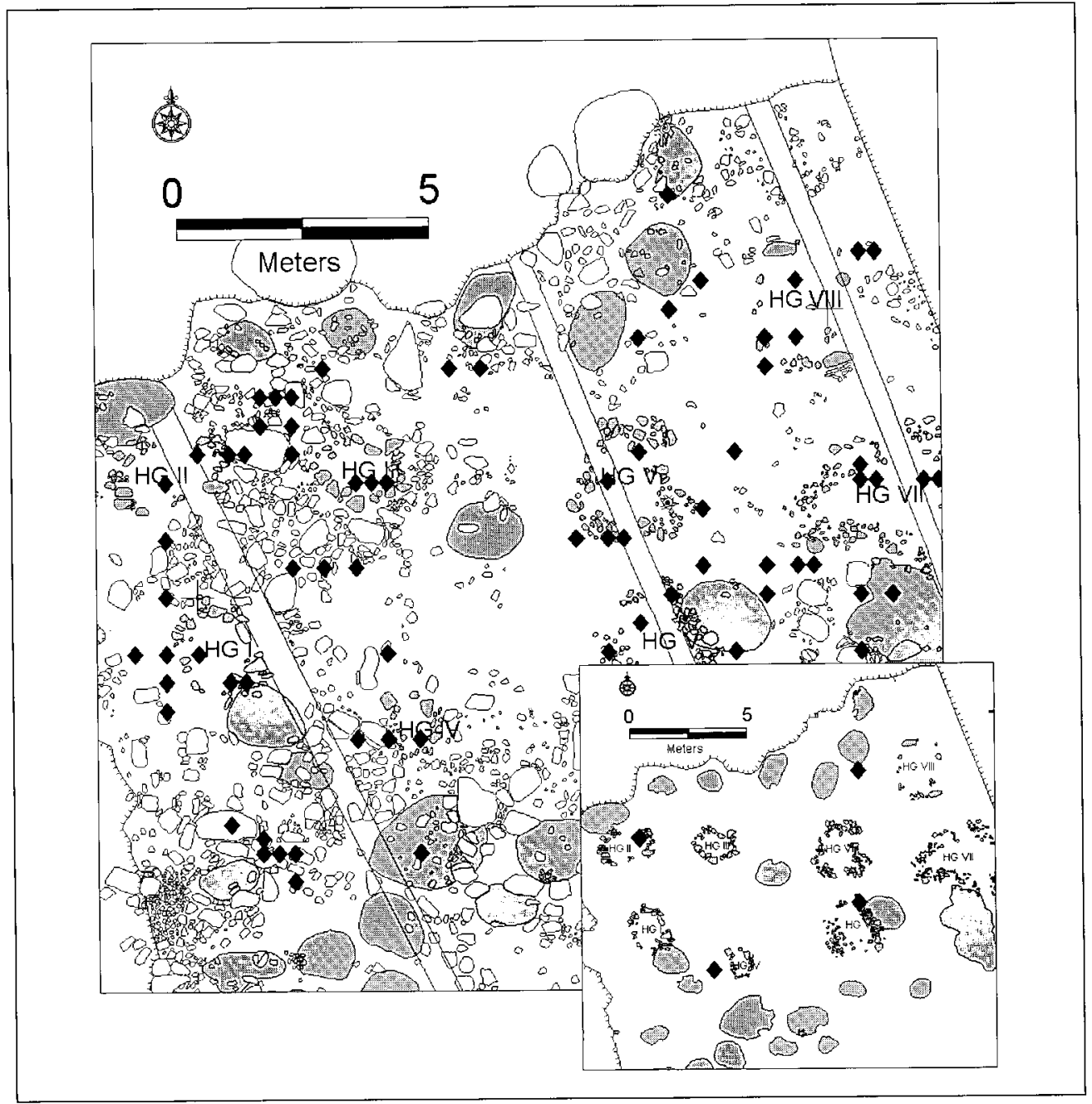

Fig. 6. The site of Frikenrönningen in plan. In the central part of the settlement hut-foundations (HG) are visible as stone circles. The squares mark artefacts made of slate and flint found on the site. Note that there is a group of artefacts in connection with every hut-foundation. The shaded areas depict piles of sand mixed with fire-cracked stones. Slate and flint do not naturally occur in the area near the settlement. The slate was transported 200 kilometers and the flint up to 700 kilometers before being deposited on the site (Lundblad 1994). The origin of the flint is Scania and the slate Grythyttan or Los. The settlement groups may have been important in a "down the line" reciprocal system of exchange (fig. 1). The little figure, below right, shows the distribution of artefacts if the site had been excavated through a $4 \%$ sampling. 
size with more sand and stone debris during use. One possible interpretation is that there are one or two cooking-pits in connection with each hut. This may be interpreted as being a repeated composition of features. This is very likely to be of relevance for interpretations concerning the social organization of the site. One possible interpretation is that every hut represents one nuclear family. Such an explanation would also account for the fact that the material was rather similar in most of the hut-foundations.

During the investigation the hut-foundations were visible as rounded stone rectangles, usually 2-4 x 3-5 meters large. Underneath the concentrations of stones which outlined the hut-foundations were postholes, usually 5-8 in each hut. Inside the hut-foundations was a cultural-layer (floor) of sand, which had been coloured by soot or was a reddish colour. This was also clearly visible in the sections which were documented in the foundations. The red colour was very common on the site in connection with the cultural-layer and features. It was noted that artefacts and ceramics usually were connected with these reddish or sooty-coloured areas and seldom were found in uncoloured sand. The cultural layers on the site were usually about 0.2 meters deep, and below this depth a large amount of features were recorded. Some graves were also documented on the site, one of which was located inside a hut-foundation. This type of inhumation with red ochre is common within the subneolithic culture (Welinder 1971; Wyszomirska 1984). The hutfoundation containing the grave was rather special. It might be interpreted as a ritual part of the settlement; there are several reasons for such an interpretation. Among other things, this hut-foundation was two times the size of the others. It also differed from the others in being the only one with clay figurines inside the walls, that is in the floor. At the same time the ceramic remains were less fragmented here than in the other hut-foundations.

The huts in the western part of the settle- ment were placed around an open stone-cleared area. In the center of this area was a hearth, and around the hearth there were very few finds. The only artefacts in this part of the site were two small pieces of flint and a little concentration of ceramics right by the hearth (Björck 1995a, in press b). In the western part of the settlement there was a similar structure, three hut-foundations encircling a relatively "cleaned" area with a central hearth. None of the hut-foundations on Fräkenrönningen were related to one another in a way that made it possible to stratigraphically determine a chronological separation. However, some of the cooking-pits seemed to be stratigraphically older than some of the huts. For example, one cooking-pit was situated under the wallremains of hut-foundation $\mathrm{V}$. In the vicinity of hut-foundation III, in the northwestern part of the terrace, there was a concentration of stones lying on stones. It seems as if the stones which had been cleared from the site during the early part of the settlement time had been deposited here. During the excavation of this part of the settlement a slate arrowhead was found directly underneath a stone, with nothing but the stone covering it. Ceramics were also found under the same circumstances in this area. Hutfoundation III seems to have been built on the northwestern area with cleared stones. The fact that this hut was built on the stones which previously had been cleared, strongly suggests that the site expanded towards the west over time. A scenario of this kind, with a difference between the eastern and the western part of the site is also suggested by the distribution of artefacts, the ceramics and the osteological materials. It seems plausible that these differences reflect a sequence in time in which the huts were not abandoned but were continuously in use. In the course of time some new huts were constructed on the terrace. The tendency could then be that as more huts were built, the settlement expanded towards the west.

The contextual data used in the recon- 


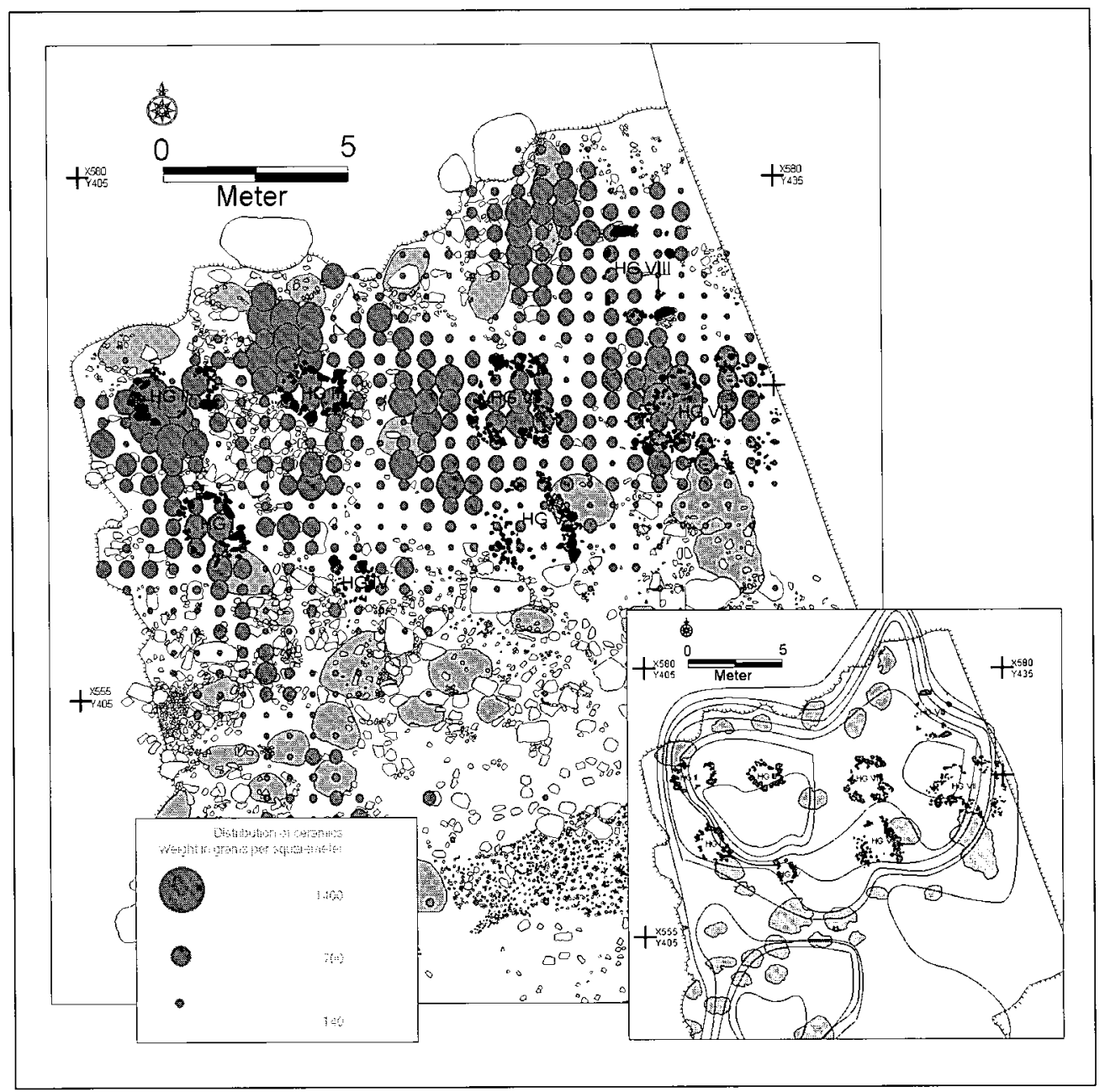

Fig. 7. The spatial distribution of ceramics on the site of Fräkenrönningen. Left: the actual distribution as documented during the contextual excavation. Right: the distribution as documented in a sampling of the site. As can be seen, the $4 \%$ sampling actually shows the opposite of the patterns seen in the contextual distribution. The "cleaned" area around the hearth is displayed as being very frequent in ceramics, and the same is true ofboth the cleaned areas in east and west. In this case the sampling resulted in the opposite of the actual distribution. This means that the sampling could actually give any kind of result. The outcome of this method has proven to be entirely stochastic and not usable for an interpretation on the intra-site level of analysis. In the light of this evidence it seems unwise to attempt analysis at the intra-site level while using a method suitable only for demarcation. 
struction of the use of space at Fräkenrönningen are entirely a result of the excavation method. It is a method which puts emphasis on intra-site structures and contextualizes the material deposited in the cultural layer. The outcome of a sampling is very stochastic and could actually be anything between an acceptable match of the real dispersion to the diametrical opposite of the actual dispersion, as in the case of the ceramic material of Fräkenrönningen (fig. 7). The outcome of the sampling presented in the contextual results above shows that materials retrieved with this method are useless for the intra-site level of analysis.

The intra-site structures of Fräkenrönningen are rich, though the interpretations presented are naturally not final. The most important result is that the contextual method of excavation has retrieved a material that is possible to use at the intra-site level of analysis.

\section{PRELIMINARY ANALYSIS:}

\section{THE INTRA-SITE LEVEL}

There are obviously intra-site structures on Stone Age sites which call for a re-evaluation of old investigation methods, such as sampling. We must critically evaluate our excavation method in the light of the questions we will apply to the material. If we are interested in intra-site structures as a possible and perhaps the only way to trace the social organization of the Stone Age society, our excavations must document features, constructions, artefacts and other evidence in the cultural layer in a way that makes them relatable to each other. We have to excavate contextually, that is excavate the whole site and document the totality of the cultural layer in connection with features. If we only partially excavate sites or sample settlements, we should direct our questions to other aspects of Stone Age life, for example, technology, subsistence and the like. I'm not sure whether we ever can fully answer questions concerning intra-site structures as a reflection of societal organization. But if we are going to try, the methods must be directed in a way that gives material suitable for these types of questions. If we, for economical or other reasons, decide to sample settlements, we shouldn't apply intra-site questions to the material. One result of the contextual excavation at Fräkenrönningen is that we now know that it may be possible to enhance our understanding of Stone Age sites through features and constructions. This may sound truistic, but if we review excavation methods utilized at this kind of archaeological sites during the last decades we will realize that it isn't. The excavation of the settlements $\ddot{A}$ s and Jonstorp may serve as examples of excavations where intra-site structures were not studied (Malmer 1969; Löfstrand 1974).

Sampling is according to the results from Fräkenrönningen, not a suitable method of excavation for the coastal sites of Norrland. Contextual excavation calls for larger areas to be opened up in order for large features to be made visible. Small-scale excavations have hence the same problems as sampling when analyzing intra-site structures, that is, this type of excavation also documents fragments of the actual remains. Since the archaeological materials consist of only a percentage, selected by culture and stochastically by taphonomy, archaeology is difficult enough without us fragmenting the materials even more. Sampling methods are excellent tools for surveys and very suitable to use while demarcating a settlement. In the dispersions displayed in figs. 6 and 7 I have shown that the distributions obtained through sampling do not reflect actual distributions on the intra-site level. In fact they may actually display any pattern from the direct opposite to a fair resemblance of the actual distribution. The problem is that we will never know what pattern the sampling happened to show at any one time. The only way to evaluate the results of sampling excavations is to conduct contextual excavations and compare the results of this work with the samplings of the 
excavated sites.

\section{MICROLEVEL SETTLEMENT PATTERNS}

An analysis of site location can put emphasis on different variables. Here I will attempt to study three such variables. Firstly, I shall consider the topography and especially in what quarter of the compass the descent of the slope is oriented. I will also consider this variable in relation to chronology. I have divided the material into two phases, younger (40 MAPSL) and older (45 and 50 MAPSL). The first two variables will in turn be compared with the third variable, namely site location. In this analysis I will only determine whether the site is situated on the mainland or an island. The hitherto DGPS-measured sites are used in this preliminary analysis, and the results may therefore change as more data are gathered.

If all hitherto measured sites are considered, slightly less than $70 \%$ of the sites are placed on slopes towards the south and almost $20 \%$ of the sites are located on slopes towards the west. The eastern and northern quarter contain slightly more than $10 \%$ of the sites. As stated above, there is a clear preference for locations on the southern slopes, followed by the western. Locations towards the east and north are less common. The sites that are oriented towards the eastern or the northern quarter of the compass are probably oriented that way for a specific reason. If we assume that the main portion of the sites are located towards the south and west for protection from northern winds and for warmth and sun, the northern and eastern sites probably are located as such for other reasons. Consequently a deeper analysis of these sites ought to tell us something about these reasons. If viewed in relation to the chronological variable, another tendency becomes apparent. All sites located on slopes towards the north are from the older isostatic levels and are situated on the mainland. More than $70 \%$ of all the sites from the older phases, as defined in fig. 2, are situated on the mainland. During the youngest isostatic level the sites are instead evenly distributed between mainland and islands. An increasing part of the sites are thus located further out in the archipelago during the later phase of the Pitted Ware culture.

There seems to be a shift in site location during the period 3800-2900 BC; in the early part of this period the Pitted Ware culture settlements are frequently located on the mainland. During the later part of the sequence a larger portion are located further out in the archipelago. The location of the sites on slopes towards the south seems to become increasingly important as the sites are established on more exposed islands in the archipelago. Of all sites, $53,7 \%$ are located on slopes towards the south during the older part of the sequence, while during the younger part $85 \%$ are located on slopes towards the south.

Correspondence between the level above the sea and typology is one way to test the shoreline displacement's relative datings. The material retrieved from the recently discovered settlements during the demarkation work has shown that the tempering material in the ceramics changes during the course of the Middle Neolithic. The percentage of chalk is increasingly greater on the younger sites. The conclusion that a chronologically related change in the tempering occurred during this time period has been drawn by several authors (e.g. Löfstrand 1974; Burenhult 1991). This observation and the measured altitude of the sites give us a stable point of departure in the chronological analysis. The chronological categories that I use in this analysis are based on these data.

\section{SITE SIZE AND CHRONOLOGY}

From the material obtained with the aid of the DGPS, it is evident that the mean size of the Pitted Ware sites decreases during the later part of the Middle Neolithic. Another variable which seems to change during the course of 
the Middle Neolithic is the actual amount of settlements. A tendency for the sites to be fewer, smaller and located further out in the archipelago in the late phase of the Pitted Ware culture, is evident. This is especially obvious in the river valleys, where great differences have been noted. The actual amount of settlements decreases over time; the tendency is obvious if we, as in this analysis, discuss in terms of two chronological periods. In the younger Pitted Ware culture there are 19 sites known, and from the older phase of Pitted Ware culture there are 54 sites known. The difference is less obvious if we work with the tripartition suggested by the DGPS measurements, but there is still a tendency for the amount of sites to decrease over time.

For the younger phase of the Pitted Ware culture we have documented site size in the interval of $277-8271 \mathrm{~m}^{2}$ while in the older horizon the site size interval is between 235 and $29147 \mathrm{~m}^{2}$. Although the distribution of settlement sizes is more or less the same in relation to each other within each chronological period - from very small sites of less than $300 \mathrm{~m}^{2}$ to very large sites of several thousand square meters - there is a clear tendency for settlement size to decrease over time.

$\begin{array}{lll} & \text { Median } & \text { Average } \\ \text { Younger } & 1924 \mathrm{~m}^{2} & 4147 \mathrm{~m}^{2} \\ \text { Older } & 2530 \mathrm{~m}^{2} & 4700 \mathrm{~m}^{2}\end{array}$

I would like to interpret the different site sizes as a reflection of land use in connection with the hunting strategy, from small hunting stations to large main settlements relating to different resources in the archipelago. The decrease in the median value as well as the value of average site size over time may be a reflection of a culture slowly diminishing. This may have been caused by social stress or a decreasing amount of hunting-prey. The social stress hypothesis rests on the assumption that the, during the later phase of the Pitted Ware culture, synchronic Battle Axe culture occupied the mouths of the rivers and hence forced the Pitted Ware culture further out in the archipelago (Welinder 1971). Another explanation for the diminishing site sizes and changing settlement locations could be an over-exploiting hunting strategy that killed off the seals and hence forced the hunters to follow the seals further out to sea.

\section{SITE SIZE AND SITE LOCATION}

It is evident from the material that the site sizes seem to be in a similar site size range within each chronological horizon. There is no obvious difference here between the archipelago and the river mouths. The tendency that within each settlement group there are great differences between site sizes is evident in every site group. This pattern of sites in differentiated sizes repeats itself in all settlement groups. In connection with the osteological evidence from the excavated site of Fräkenrönningen, which indicated that this site was used all year round (Olson 1994, 1996), I would like to explain the settlement groups in a social framework. Since the sites have been used all year round the life-style would have been sedentary. It is hardly surprising that the coastal dwellers of the Middle Neolithic have been domiciled, since the ecotop in which they pursued their livelihood was abundant in resources. The settlement groups may be explained as tribal territories or, for instance, an area of one lineage within a tribe, that is a remnant of some kind of Middle Neolithic social group. This line of reasoning would also explain why the range of site sizes is similar in every settlement group. A similar group size (lineage/ tribe), utilizing a similar landscape and its coastal resources in the same way, should leave the same types of special purpose sites, hunting stations and main settlements. An interpretation of the similar settlement patterns in the respective settlement groups as the result of a similar social organization, would explain this resemblance.

If emphasis is laid on the relative size of the settlements, such a pattern ought to be 
detectable. Using the above-mentioned site size average, the settlements can be divided into two groups, larger than or smaller than average. If these site sizes are then analyzed in relation to site location on islands or the mainland the following pattern emerges. In the case of smaller sites, the sites are evenly distributed on the mainland and islands, with a slight predominance for the island location. In the case of the large settlements there is a clear emphasis on locations on the mainland. Only $25 \%$ of these sites are located on islands, while $75 \%$ are situated on the mainland. The overall tendency of this analysis is that the larger sites are located on the mainland and the smaller sites usually are found on islands. These patterns are blurred by the fact that there seems to be a change towards smaller sites during the later phase of the Pitted Ware culture. The described pattern therefore may be chronological rather than a reflection of synchronic resource utilization. Other source-critical annotations are the difficulty of determining site size and the site location. I have used the overall site size average and the distinction island/mainland as a point of departure. This angle may, however, over-simplify the matter. A large island may have been viewed as mainland, and a peninsula that stretches far out in the archipelago would have many qualities in common with islands. Another problem with the angle I have used is the above-mentioned chronological patterns, which may call for a use of relative site sizes instead of the definitions I have used.

Many different levels can be analyzed when discussing a prehistoric culture. We can study the intra-site level, that is settlement structure. We may also study the regional groups within a settlement group, a level highly suited to the fieldwork presented. In the macroperspective we can study the settlement groups and their relations. I would like to stress that all these levels have an important function in understanding the culture. All of the above may actually be a reflection of the social organization that once existed. These patterns are of course blurred by the fact that subsistence strategy, taphonomy and other variables have altered them. This makes it even more obvious that we need all these analytic levels if we are to reach an understanding of Stone Age culture.

\section{MACROLEVEL SETTLEMENT PATTERNS}

I have already presented the macrolevel patterns as they are documented up to today. In fig. 1 a pattern with site agglomerations along the Middle Neolithic coastline is visible. There seems to be some relevance in a statement that connects these settlement groups with the rich natural enviroments by river mouths and archipelagos. This line of explanation are not able to explain the patterns in their entirety, that is there are river mouths without settlements and settlements without river mouths. At the same time the regularity of the settlement groups along the coast needs to be explained. This regularity may be a reflection of the social organization and may be interpreted as, for example, tribal territories. This explanation draws on the idea that culture and people organize, not nature. An explanation of this kind is tempting but hard to prove and defend. Through large-scale excavations and evaluations of, for example ceramics, we might close in on this type of question. The use of material culture as social markers is well known. For example, the ornamentation on ceramic vessels might be a category of relevance for this question. Today these questions are simply beyond what the existing material can tell us; the settlement pattern as documented lends itself to many other lines of explanation.

An interesting part of the pattern is that there definitely is a continuity of settlement in all the documented groups. The whole body of groups have sites from the oldest to the youngest part of the Middle Neolithic. An explanation of the documented pattern can not be of chronological origin. Hence we 
may rule out the natural and the chronological models in our attempts to explain it.

\section{SUMMARY}

The Pitted Ware culture in southern Norrland represents the northernmost sites of this cultural expression and should therefore, according to the above-mentioned circumstances, generally be more suitable for intra-site analysis than other sites within the culture. The time at which the sites were suitable for coastal dwelling is shorter in this area than anywhere else. At the same time, the rapid shoreline displacement has caused chronologically separated sites in the research area to be spatially more separated than in other parts of Sweden. This gives us an unique opportunity to study changes in the settlement pattern over time more clearly than anywhere else within the Pitted Ware culture. In order to make use of this great potential a largescale survey, aimed at locating Middle Neolithic sites in the county of Gävleborg, was initiated during July 1995.

Above I have presented the subneolithic culture of southern Norrland at three different analytical levels. First I have presented the settlement structure as documented by surveys of the past years. The regularity of the settlement agglomerations and the amount of sites have been briefly discussed. The survey has shown that the settlements in Hälsing-land are part of the same cultural expression as the sites in Gästrikland. Besides the typo-logical similarities there is an unbroken chain of settlements that brings them together. The distance between synchronic, Middle Neolithic site agglomerations in Gävleborg does not exceed 15 kilometers. On the site of Fräkenrönningen some ceramic sherds of the same type as those found on Hedningahällan were retrieved. The close similarity between the ceramic material from the sites is another circumstance that tells us that the sites of Hälsingland and Gästrikland were once closely connected. The macrolevel settlement pattern has been suggested to be a result of the social organization.

Through a study of settlement size and chronology, a discussion of settlement patterns within the site agglomerations has been presented. The settlement structure within each settlement agglomeration has been suggested to be a result of the Middle Neolithic hunting strategy. On the intra-site level the settlement structures at Fräkenrönningen were interpreted as the result of a group consisting of several nuclear families living sedentarily on a coastal site. This group might have been using several hunting stations in the vicinity of Fräkenrönningen, as suggested in the microlevel settlement pattern. I have also presented an excavation of this kind of site and discussed excavation methods. A hypothetical model for the use of space at this site has also been presented. In this model finds, datings, structures, depositional patterns and stratigraphic evidence have aided the evaluation.

Our efforts are now directed towards retrieving a material suitable for analyzing the three levels mentioned. The surveys are directed towards the macrolevel settlement patterns and will give a clearer view of settlement groups and site locations. The DGPSmeasurements and demarcations are done in order to understand the microlevel settlement patterns with settlement size and chronology. The excavations conducted in this region during the past years are directed towards an understanding of the intra-site level of the Middle Neolithic settlements.

In order to put forward a reasonable reconstruction of the prehistory, we need to study archaeological cultures at all these levels. The multidimensional approach contextualizes all levels of the material through cross-references from one level to another. All different analytical levels have in this perspective relevance for the interpretations of other dimensions of the culture. The organization of a special purpose site might consequently be a reflection of both the hunting strategy and the social system, that is, the 
intra-site level, microlevel and macrolevel. Therefore it should, if possible, be interpreted/understood in this context.

English revised by Laura Wrang.

\section{REFERENCES}

Andersson, A. et al. 1994. Från stenålder till kolmila - Inventeringsrapport om ett kulturlandskap med kontinuitet i Högs sn, $\mathrm{Hu}$ diksvalls kommun. Hudiksvall.

Baudou, E. 1977. Den förhistoriska fångstkulturen i Västernorrland. Västernorrlands förhistoria. Motala.

- 1992. Norrlands forntid - ett historiskt perspektiv. Förlags AB Wiken.

Björck, N. 1995a. Fräkenrönningen - En by från gropkeramisk tid. Läddikan 1/95. Pp. 7-9. Gävle.

- 1995b. Neolithic cultural affinities and the northernmost border of pitted ware culture. Kontaktstencil XXXVIII 1995. Köpenhamn.

- 1996a. Vad har lågteknisk järnhantering och bosättningsmönster under yngre stenålder gemensamt? Centrum och periferi - relativa begrepp som analytiska redskap. Kontaktstencil XXXIX 1996. Pp. 65-89. Umeå.

-1996b. Fördjupad utredning av E4 NorralaEnånger. Rapport Länsmuséet Gävleborg. Gävle.

- in press a. Mellanneolitikums kustbundna boplatser. Bottnisk Kontakt VII 1994. Piteå.

- in press b. Fräkenrönningen - en by för 5000 àr sedan. Rapport Länsmuséet Gävleborg. Gävle.

- in prep. Yngre stenålderns kustboplatser. Rapport Länsmuséet Gävleborg. Gävle.

Blomqvist, L. 1989. Neolitikum -Typindelningar, tid, rum och social miljö. Falköping.

Broadbent, N. 1978. Arkeologi och landhöjning i norra Västerbotten - en kritisk undersökning. Studier i norrländsk forntid. Umeå.

- 1979. Coastal Resources and Settlement Stability - a critical study of a Mesolithic site complex in Northern Sweden. AUN 3. Uppsala.

1982. Skelleftebygdens historia - den förhistoriska utvecklingen. Uppsala.

Browall, H. 1991. Om förhållandet mellan tratt-

\section{ABBREVATIONS}

MAPSL Meters above present sea-level

DGPS Differential Global Positioning System

GIS

bägarkultur och gropkeramisk kultur. Västsvenska stenåldersstudier. Göteborg.

Burenhult, G. 1991. Arkeologi i Sverige I. Höganäs.

Ericson, P. 1989. Säl och säljakt i Östersjöområdet under stenåldern. In: Iregren, E. \& Liljeqvist, R. (Eds). Faunahistoriska studier tillägnade Johannes Leepiksaar. Report series 33. Lund.

Florin, S. 1958. Vråkulturen-Stenåldersboplatserna vid Mogetorp, Östra Vrå och Brokvarn. Stockholm.

Forsberg, L. 1985. Site variability and settlement patterns. An analysis of the hunter-gatherer settlement system in the Lule river valley 1500 $B C-B C / A D$. Archaeology and Environment 5. Umeå.

Gräslund, B. 1978. Sill och sillfiske i Östersjön under stenăldern. Tor vol. XVII. 1975-1977. Uppsala.

Hallgren, F. 1993. Bosättningsmönster i gränsland. Seminar paper. Uppsala.

Holm, L. 1995. Stenåldersboplatsen vid Dalkvarnsbäcken. Julhälsning till Forsa och Högs församlingar. Stencil.

Jonsson, A. 1958. Stenåldersboplatsen vid Mårtsbo. Tor vol. IV. Pp. 26-41. Uppsala.

Kihlstedt, B. 1996. Neolitiseringen i östra MellanSverige - några reflektioner med utgångspunkt från nya ${ }^{14} \mathrm{C}$-dateringar. In: Peter Bratt $(E d)$. Stenålder $i$ Stockholms län. Stockholm.

Lundblad, M. 1994. Skiffer och flintartefakter. Analys och härledning av stenmaterialet frän den gropkeramiska boplatsen Fräkenrönningen, Valbo sn, Gästrikland. Seminar paper. Stockholm.

Löfstrand, L. 1969. Den gropkeramiska kulturens nordgräns och kontakter med norrländsk stenålder. Nordsvensk forntid. Pp. 81-98. Umeå.

- 1974. Yngre stenålderns kustboplatser. Aun 1. Uppsala. 
Malmer, M. P. 1962. Jungneolithische Studien. Acta Archaeologica Lundensia. Lund.

- 1969. Gropkeramikboplatsen Jonstorp RÄ. Antikvariskt Arkiv 36. Stockholm.

Miettinen, M. 1990. Om stenålderns fångstbosättning i Kvarkenområdet. Bottnisk Kontakt $V$ 1990. Raumo.

Olson, C. 1994. Djurbensmaterialet frän Fräkenrönningen. En mellanneolitisk kustboplats $i$ Valbo sn, Gästrikland. Seminar paper. Stockholm.

- 1996. Osteologisk undersökning - Fräkenrönningen, Valbo sn, Gästrikland. Stencil.

Olsson, E. 1996. Neolitikum i Stockholms länkällmaterial och forskningsläge. In: Peter Bratt (Ed). Stenålder i Stockholms län. Stockholm.

Schierbeck, A. et al. 1994. Hedningahällan - en undersökning för att skydda och vårda. Rapport 1994:3. Stockholm.

Segerberg, A. 1995. Torslunda i Tierp - En mellanneolitisk boplats. Tor vol. 27:1. Pp. 185-231 1995. Uppsala.

Siiriäinen, A. 1969. On the cultural ecology of the Finnish Stone Age. Suomen Museo 1980. Pp. 540. Helsingfors.
Sundlin, H. 1974. 4 förhistoriska boplatser frain norra Hälsingland-en preliminäranalys. Seminar paper. Stockholm.

Welinder, S. 1971. Överåda - A Pitted Ware Culture Site in Eastern Sweden. Meddelanden frän Lunds Universitets Historiska Museum. 19691970. Pp. 5-99. Lund.

- 1978. The Acculturation of the Pitted Ware Culture in Eastern Sweden. Meddelanden frän Lunds Universitets Historiska Museum. 197778. Lund.

Wyszomirska, B. 1984. Figurplastik och gravskick hos Nord-och Nordösteuropas neolitiska fångstkulturer. Acta Archaeologica Lundensia. Lund.

Åkerlund, A. 1996. Human responses to shore displacement-Living by the sea in Eastern Middle Sweden during the Stone Age. Riksantikvarieämbetet arkeologiska undersökningar. Skrifter nr 16. Stockholm.

Österholm, I. 1989. Bosättningsmönstret på Gotland under stenåldern. En analys av fysisk miljo, ekonomi och social struktur. Theses and papers in archaeology 3 . Stockholm. 
